\title{
Freudian Notion of Psychoanalysis: Its Implications in Contemporary Teaching Practices
}

\author{
Muhammad Afzal Awan* \\ English Language Institute, King Abdulaziz University, PO box 80200, Jeddah 21589, KSA
}

Corresponding Author: Muhammad Afzal Awan, E-mail: maawan19@yahoo.ca

\section{ARTICLE INFO}

Article history

Received: July 13, 2017

Accepted: October 08, 2017

Published: October 31, 2017

Volume: 8 Issue: 5

Advance access: October 2017

Conflicts of interest: None

Funding: None

\section{Key words:}

Psychoanalysis,

Aggression,

Unconscious Drives,

Conscious Self,

Teaching Practices

\begin{abstract}
The author has engaged in a critical review of Frued's notion of psychoanalysis and its vitality in teaching. Illustrating from Freud's own assertions and through the interpretations of the later critics, the author has pointed out certain noticeable pitfalls and, or incapacities of contemporary teaching practices. The forces of aggression and sex exert their influence through the unconscious drives to make teaching, holds Freud, one of the 'impossible' professions. Impossibility of teaching does not imply an absolute failure of all what education stands for, but it refers to the challenges of the problematic nature of the profession. Teaching a child entails a tug of war between 'conscious self' and 'unconscious drives'. This tug of war is organized by illconceived notions of love, kindness, motherhood associated with teachers. On the contrary, the contemporary teaching practices are guided by coercive methods of subjugation, standardized tests and institutional control. None but the leaner suffers in this predicament. This is how more damage than the benefit is suspected from education. The author concludes that a more liberal environment can create a space for the leaner to appease the vulnerable impulses of sex and aggression without affecting the natural creativity which is probably the greatest intrinsic capital to invest for great gains. Frued's notion of psychoanalysis can be a means to an end but not an end in itself. It can defend teaching from failing in its pursuits; if the failure is predetermined, teachers may fail honorably rather than miserably.
\end{abstract}

\section{INTRODUCTION}

Teaching was not institutionalized as such in the primitive times, but at the dawn of the new millennium, the established schooling tradition of the past many centuries seem staggering; non-formal education and homeschooling are gaining momentum. Almost 1.8 million children were homeschooled circa spring of 2012 in the United States only. (Noel, Amber, Stark, Patrick, Redford, Jeremy. 2013). The reasons behind this divergence from the established educational track may be of economic, racial, social, religious, administrative and security nature. However, this paper shall focus on just one aspect- the incapacity of the current teaching practices with specific reference to Freud's notion of psychoanalysis. Freud himself did not say much about the role of psychoanalysis in education but, if we see the contemporary teaching practices with his lens, as it will be substantiated in this article, there seems a great promise.

Educating a human being is a herculean task. It is highly complex and problematic to reach an accord as what to teach, how to teach and after all why to teach? It is pertinent to quote here a dialogue from the ancient history of teaching and learning. This is how one of the prototype fathers of pedagogy is so vehemently asserting the complexity, implausibility and 'impossibility' of teaching:
Meno: Can you tell me, Socrates, if virtue can be taught? Or is it not teachable but the result of patience, or is it neither of these, but men possess it by nature?

Socrates: ....You must think me happy indeed if you think I know whether virtue can be taught.... I am so far from knowing whether virtue can be taught or not that I do not even have any knowledge of what virtue itself is..........

Meno: Yes Socrates, but how do you mean that we do not learn, but that what we call learning is recollection? Can you teach me how this is so?

Socrates: ....Meno, you are a rascal. Here you are asking me to give you my "teaching", I who claim that there is no such thing as teaching, only recollection. (Quoted in Felman 1982)

Psychoanalysis and education: Looking into the nature and process of teaching, if we acknowledge it to be a process at all, Freud's theory of psychoanalysis and its subsequent discourses over the span of more than a century by now, have reconfirmed that teaching is one of 'the impossible professions.' Establishing links between Freud's theory of psychoanalysis with education or pedagogy is very problematic. Freud himself put forth his personal contribution in this area in the following words:

"None of the applications of psychoanalysis has excited so much interest and aroused so many hopes, and none, 
consequently, has attracted so many capable workers, as its use in the theory and practice of education.... My personal share in this application of psychoanalysis has been very slight." (The Complete Psychological Works of Sigmund Freud. The Hogarth Press XIX, P.27)

Anna Freud (1981) has pointed out that Freud left others to this work for further exploration. Freud drew the attention of his audience and indeed his disciples to the significance of psychoanalysis in the context of education:

"But there is one topic which cannot pass over so easily-not, however, because I understand particularly much about it or have contributed very much to it. Quite the contrary; I have scarcely concerned myself with it at all. I must mention it because it is so exceedingly important, so rich in hopes for the future, perhaps the most important of all the activities of analysis. What I am thinking of is the application of psychoanalysis to education" (The Complete Psychological Works of Sigmund Freud. The Hogarth Press XXII, 146).

Though Freud's disciples have not left the field unexplored yet there is generally scarcity of literature on this vital issue. For example, Britzman (2011) asserts that many people, upon learning about her book entitled "Freud and Education" expressed surprise at the topic. The reason, she contends, why people think Freud had not to say much about education is the erroneous perception about education such as taking education as mere the task of school, currency of good or bad curriculum. The typical expectations assigned to education are generally the transfer of knowledge and skill, and ability of learners to memorize and reproduce the information inculcated in them, and the focus on 'product' through traditional standardized tests. These predominant features of education have perhaps further narrowed the scope of what Freud and his followers conceived of education both implicitly and explicitly.

When we say something is impossible, it may not simply mean that the chapter is closed. Its implied meanings as Felman (1982) intrigues us to ask, "what can be learnt from the fact that it is impossible to teach and what can the impossibility of teaching teach us?' To reflect on a few selected facets of psychoanalysis in relation to education, I have divided the discussion into the following subtopics:

\section{Theoretical Premise of Psychoanalysis}

Freud himself proclaimed at many occasions that his theory of psychoanalysis was neither easy to explain nor simple to understand, apart from its moral and emotional effects and distastefulness (1910a, p, 28 etc). To keep the discourse simple enough for my readers, I am borrowing from Bibby (2011) the following basic assumptions which contain key ideas of psychoanalysis:

a) That we possess a dynamic unconscious that we never access directly or know completely

b) That we are constituted with defenses, we are 'defended subjects' and

c) That our unconscious is an irrefutable reality

Freud identified that the unconscious is burdened by repression, predominantly of the instincts of sex and aggression, and is highly unlikely to be accessed without psychoanalysis.
The notion of an unknown and fundamentally unknowable unconscious can be unsettling as it wrests the illusion of our self-control and self-knowledge from us. (Bibby 2011:7). Stephen Frosh (2002) has further elaborated this:

"What we are taught to see as 'natural' in the human condition, the capacity to use reason, is only a small part of the story: behind every action is a wish, behind every thought is an unreasonable desire. Psychoanalysis thus challenges the Western view that the distinguishing mark of humanity is reason and rationality, arguing instead that human 'essence' lies in unacceptable and hence, repressed impulses towards sexuality and aggression."

To understand the impact of this repression, it is pertinent to focus on its outcome named as 'phantasies'. (The spelling 'phantasy' is used to separate unconscious desires and wishes from conscious 'fantasy' (Bibby 2011:153). Freud told that the unconscious was one of the most 'dynamic' elements; he held unconscious rather more active, dynamic and energetic than the conscious mind. (Bibby 2011). The very nature and function of unconscious is totally different from the conscious. At the conscious level, anxieties may be named and talked about, whereas at the level of unconscious, just like 'out of sight out of mind', anxieties continue to wield their considerable power beyond the rationalizing influence of language. (Walkerdine, Lucy and Melody 2001). This is how, we come to know that learning and teaching is hardly an exchange of information, construction of knowledge and processing of information whatever a traditional stance may claim, rather it is something far more complicated. A direct transfer of knowledge and skill as it apparently appears to be doable, is highly complicated, if seen in the Freudian psychoanalytical sense.

It is very significant, therefore, to understand the unconscious with respect to individual's personal context and in the wider social context because education is by all means a social issue. Both the person's unconscious and the society may support or contradict each other. The unconscious is largely shaped up in the social context. Whatever is deeply embedded in the unconscious, and later repressed for partly social reasons and partly personal reasons (which are indeed predominantly social again), often lacks the language or any other mode for its expression. But one thing is sure, inaccessible or unapproachable it may be, unconscious does exist and does exert its influence. Bibby (2011) points out that 'not only does our unconscious affect us and those around us; so too do society and culture shape our unconscious. On the pretext of this interdependence of each other and inseparability, it can be legitimately claimed that we, the human beings are intrinsically socio-psychological beings. Society and man bear up as well as damage each other. In his essay 'Civilization and its discontent', Freud (1930) expressed that while society or civilization is constituted to ease the difficulties of living life, 'it simultaneously creates other difficulties in living life.' Freud suggests that 'civilized man has exchanged a portion of his possibilities of happiness for a portion of security'. At certain angle, it seems that teaching a child is nothing other than making the child sick and neurotic. Education has its methods that control and restrict 
the instincts, and this social conditioning ends up in an irreparable loss of the very personality of the child. It is just like a tug of war between the conscious self and unconscious 'drives'. In this tug of war, each force tries to nullify the influence of the other. Freud is known for his mastery of using fact and fiction with such a splendid skill. He employs mythical language; the metaphors of Scylla and Charybdis are to clarify this tug of war; he proclaims:

"The child must learn to control his instincts. It is possible to give him liberty to carry out all his impulses without restriction.... Accordingly, education must inhibit, forbid and suppress and this is abundantly seen in all periods of history. But we have learned from analysis that precisely this suppression of instincts involves the risk of neurotic illness... Thus education has to find its way between the Scylla of non- interference and the Charybdis of frustration.... An optimum must be discovered which will enable education to achieve the most and damage the least.... A moment's reflection tells us that hitherto education has fulfilled its task very badly and has done children great damage." (Freud. 1933: 149)

From this perspective, some critics of Freud have gone to the extent of dubbing Freud as the "anti- pedagogue". (Millot 1979). To avoid digression, I would quote Anna Freud who opines: 'Psychoanalysis whenever it has come into contact with pedagogy, has always expressed the wish to limit education. Psychoanalysis has brought before us the quite definite danger arising from education.' It is in this sense that Felman (1982) suggests teachers to conceive more liberal methods for raising children; what he means is to strike 'the right proportion of instinct-gratification and instinct-restriction.'

\section{Contemporary Teaching Practices}

Our typical educational practice revolves round the notions of love that further problematizes the nature of the job. The sentiment of love cannot be imagined to be like rain to shower on hero and villain alike. The idea of love involves acceptance and rejection, change in moods, variation of intensity and transfer of ownership. School replaces or tries to replace the parental love with teachers' love. As child is the centre of all what education stands for, the terms like 'child', 'childhood', and 'children' are still being given diversified connotations in the recent history of sociology. (James and James 2004; Mayall 2002). For example, a common cliché 'Every Child Matters' provokes a Pandora box of new concerns as points out Bibby (2011): 'Do all children matter equally?' Does the child, she questions, matter as much and in the same manner as the one who engages in criminal activities, and again is it fair to compare a lazy bone with the one whose intellectual ability can surprise teachers and parents alike?

Similarly, perhaps owing to our sheer oversimplification of the matter, we generally associate innocence with childhood and absolute kindness with teachers, a second name of 'motherhood', but there are abundant stories in the press which prove the opposite to be true. For example, the recent report of a female nursery worker who abused very young children and spread their photographs on internet (Morris
2009), is a case in point. It is not by chance that every state is concerned about background checks of teachers and youth trainers. They are to undergo background checks like criminal record bureau (CRB) before assigning the task of child or youth care to them. It means that children or youth are vulnerable and the elders are not. (Bibby2011). It is perhaps due to similar general notions that there is always a wide schism between the youth and age.

Sex and violence are the most dominant instincts but left somewhere in the darkroom in our traditional educational practices. Violence and sexual assaults do not erupt as a matter of chance and must not be taken as accidents; they are to be found out from within the recesses of human nature through redefining Freud's illustrious notion of psychoanalysis which has not gained the significance it deserves in the contemporary educational arena. What we seriously lose or miss in our endeavor to design and implement the pre-determined teaching agenda without predefined outcomes, is the act of ignoring or under-valuing the anxieties and phantasies of child. By creating lists of important knowledge, we soothe ourselves into believing that wise choices have been made; nothing important will be forgotten.... But the knowledge not on the list keeps intruding; the elephant does not leave the room. (Bibby 2011). Educational practices generally create an industry like culture in school settings. Top down policies are usually the order of the day and strict adherence is the ideal of school management. Nothing is more alien to the creativity and independent thinking than 'compliance' and commonly known 'zero tolerance' policy. Britzman (2003) rightly contends, 'When this occurs, perceptions of the world become more and more literal and aggressive, and capacity for thinkers to think is attacked.' This kind of control policies and policing practices drown the anxieties and phantasies of learners too deep not to be found easily. Punishments, threats and control tactics are justified and perpetuated; to get hold over the suspected vulnerability of youth, a variety of control methods are enforced and justified. Taubman (2006) maintains:

"The fantasies of loss of control that haunt student teachers and perhaps all teachers hold in fact very powerful aggressive impulses that are defended against fantasies of loving and sacrificing for students....Higher standards and high stakes testing, corporal punishment, tough-love, the end of social promotion, and the end of affirmative action, all these offer opportunities for teachers to enjoy their own aggression in the name of greater good and actually, in some cases, to have the double enjoyment of turning such aggression into sacrifice: 'This hurts more than it hurts you', as the punishment is made out."

The educational practices codify knowledge and make it a quantity that can be pre-calculated, imparted and evaluated in empirical terms. 'A Master of Arts' and similar titles given in education, points out Lacan (1996), protect the secret of substantial knowledge. This quantification of knowledge is open to dispute. Every week, every month, every term, every academic year finds a calculated input and an expected output. Schools appear to be trademark industries and very little space is left for thinking, pondering and self-reflection. The 
entire system ends up in what Menzies Lyth (1960) calls, 'splitting up of caring relationships and depersonalization, categorization and denial of significance of the individual.' These control methods and defense mechanisms eventually leave little space for original creative impulses in the learners; Britzman rightly contends:

"Habits of avoidance - inhibitions of curiosity - are cultivated in education as a defense against its structures of authority, dependency, and interference. And these strategies, affected by what they defend against, also preserve the anxiety of learning." (Britzman 2003:4).

\section{Future Dimensions}

What should be done to incorporate the psychoanalytical perspective in contemporary educational practices is a fundamental question. Felman draws our attention to this vital concern and asserts that 'pedagogy in psychoanalysis is not just a theme, it is a rhetoric, it is not just a statement, it is an utterance, it is not just a meaning, it is action, an action which itself may very well, at times, belie the stated meaning, the didactic thesis, the theoretical assertion.' It is, therefore, a high time to redefine education with the lens of psychoanalysis. I can safely claim what Freud himself referred to while discussing 'The Teaching of Psychoanalysis in Universities' that psychoanalysis is a mean to an end and not the end in itself. Freud expressed: " ...it will be enough if (the student) learns something about psychoanalysis and something from it. (Freud The Complete Works: XVII:173). Felman (1982) has to say that psychoanalysis, in this sense, is not a simple object of the teaching but its subject. Lacan (1996) points out that what really matters is 'how can what psychoanalysis teaches us be taught?"

\section{CONCLUSION}

These are some of the reasons why Freud had considered education as one of the 'impossible professions'. It is perhaps, owing to the very nature of the work teachers do, hints Britzman (2011), 'as teachers through their teaching exert influence on others, the force of education expands to unimagined scenes'. In practical reality, this highly multilayered task has been narrowed down beyond imagination. Teachers are faced with high degree of dependency and surrender to the so called lines which are usually mapped out by the ones who are generally miles away from the real life situations of classrooms where psychosocial encounters of learners and teachers take place. Financial, institutional, and legal threats and enticements are deployed with increasing force and fury to get teachers submit to standardized approaches to curriculum and instruction (Kliebard 1986). Such approaches run quite counter to most teachers' sense of calling as well as to their convictions and intuitions about what makes good teaching. (Cuban 1993). Of course, there are many socio-historical causes of this perennial project to both homogenize and trivialize what teachers teach and how they teach it. (Tyack 1974). Finally, what should be done in order to carry out this job whose success is doubtful right from the outset? Freud himself hinted: '(Education is a pro- fession in which) one can be sure beforehand of achieving unsatisfactory results.'(Freud,1977:248). It is too hard to find an easy answer to this very complex question. It is frustrating to note the agony what (Bass 1998; Brtzman2003) share by saying that there is no simple recipe for how to behave in classrooms and to avoid falling into the trap of systematicity. I would end up with two notes: teachers must remember that depth is all. Gone are the days that Bruner's constructivist model was order of the day. It is high time to redefine in the psychoanalytical terms that teaching is not mere a surface ability of the learner to conceptualize, it is his or her whole person involved in picturing 'how to conceive a squared root, a declined verb, a balanced equation, the plural of deer; or the harshness of the Arctic environment, or the nature of myth, or the varieties of human conflict regulation-or the meaning of infinity'. (Jones 1968). And secondly, there is no sport that is bound to end in success. If teaching is predestined to meet failure, it should not fail miserably; it should meet a failure gracefully. To conclude, there is a dire need on the part of teachers to be aware of the more powerful nature of the unconscious drives of the learner than the surface power of his or her conscious self. A truly liberal teaching methodology and liberal treatment can save the vitality of the teaching and learning space.

\section{REFERENCES}

Bass, A. (1998) Sigmund Freud: the questions of a Weltanschauung and of defense. In P. Marcus and A. Rosenberg (Eds), Psychoanalytic versions of the human condition: philosophies of life and their impact on practice (p-412-46). New York and London: New York University Press.

Bibby, T. (2011) Education - An 'Impossible Profession'?: Psychoanalytic exploration and classrooms. Routledge: Foundations and Future of Education.

Britzman, D. (2003). After- education: Anna Freud, Melanie Klein and psychoanalytic histories of learning. Albany: State University of New York Press.

Britzman, D. (2011) Freud and Education. Routledge Key Ideas in Education Studies.

Cuban, L. (1993). How teachers taught: Constancy and Change in American Classrooms, 1890-1990. New York: Teachers College Press

Felman, S. (1982) Teaching Terminable and Interminable. The pedagogical Imperative: teaching as literary genre pp.21-44.

Freud, S. (1910) (1953-1974), The Standard Edition of the Complete Works of Sigmund Freud. Five Lectures on Psychoanalysis. SE 11, 9-55.

Freud, S. (1930). Civilizations and its discontents. In J. Strachey (ed.) The Standard Edition of Complete Psychological works of Sigmund Freud. (Vol. XXII, 1932-36). pp. 136-37. London; Vintage.

Freud, S. (1933). Lecture XXXIV: Explanations, applications and orientations. In In J. Strachey (ed.) The Standard Edition of Complete Psychological works of Sigmund Freud. (Vol. XXII, 1932-36). pp. 136-37. London; Vintage. 
Freud, A. (1960). Psychoanalysis for Teachers and Parents, translated by Barbara Low (Boston: Beacon Press) pp.95-6.

Freud, A. (1981). A study Guide to Freud's writing (1978). In Psychoanalytic Psychology of normal development (1970-1980), The Writings of Anna Freud. Vol. VIII, 209-276. New York: International University Press.

Frosh, S., (2002). Key Concepts in Psychoanalysis. London; the British Library.

James, A., \& James, A.L. (2004). Constructing childhood. Basing stroke: Palgrave Mac Millan.

Jones, R. (1968) Fantasy and feeling in education. New York: New York University Press.

Kliebard, H. (1986). The struggle for the American Curriculum. 1893-1958 New York: Routledge

Lacan, J. (1996). Ecrits: the first complete edition in English: Editions du Seuil.

Mayall, B. (2002). Towards sociology for childhood: Thinking from children's lives. Maidenhead. Open University Press.

Menzies, L. I. (1960) Social systems as defense against anxiety. Reprinted in P.du Gay, J. Evans and P. Redman (Eds), Identity: A READER (2000) P-163-82. London:
Sage in association with The Open University.

Millot, C. (1979). Freud Anti-Pedagogue. Paris: Bibliotheque d'Ornicar.

Morris, S. (2009, 13 October). Child Abuser Venessa George Admits her Crimes were 'disgusting and vile'. The Guardian. Retrieved: January 2010 from http://www. guardian.co.uk/uk/2009/oct/13/child-abuser-venessa-george.

Noel, A., Stark, P. \& Redford, J. (2013). Parent and family involvement in education, from the National Household Education Surveys Program of 2012. Washington, DC: National Center for Education Statistics, Institute of Education Sciences, U.S. Department of Education.

Taubman, P.M. (2006). I love them to death. In G.M. Boldt and P.M. Salvio (Eds), Love's return: psychoanalytic essays on childhood, teaching and learning (pp. 19-32). London: Routledge.

Tyack, D. (1974). The one best system: A history of American urban education. Cambridge, MA: Harvard University Press.

Walkerdine, V., Lucy, H., and Melody, J. (2001). Growing up girl: psychosocial explorations of gender and class. London: Palgrave. 